\title{
Emerging roles of lymphatic endothelium in regulating adaptive immunity
}

\author{
Catherine M. Card, Shann S. Yu, and Melody A. Swartz \\ Institute of Bioengineering and Swiss Institute for Experimental Cancer Research, School of Life Sciences, \\ École Polytechnique Fédérale de Lausanne, Lausanne, Switzerland.
}

\begin{abstract}
Emerging research on the roles of stromal cells in modulating adaptive immune responses has included a new focus on lymphatic endothelial cells (LECs). LECs are presumably the first cells that come into direct contact with peripheral antigens, cytokines, danger signals, and immune cells travelling from peripheral tissues to lymph nodes. LECs can modulate dendritic cell function, present antigens to T cells on MHC class I and MHC class II molecules, and express immunomodulatory cytokines and receptors, which suggests that their roles in adaptive immunity are far more extensive than previously realized. This Review summarizes the emergent evidence that LECs are important in maintaining peripheral tolerance, limiting and resolving effector $T$ cell responses, and modulating leukocyte function.
\end{abstract}

\section{Introduction}

Our appreciation for the varied functions of lymphatic vessels has evolved from different scientific disciplines. Traditionally, microcirculatory physiologists studied the essential transport functions of lymphatic vessels in removing fluid, molecules, and cells after leaking from blood vessels in the periphery and before returning them to the blood circulation. Lymph indicated the state of the local interstitial fluid it drained, with Starling forces dictating fluid and solute balance (1-3). Immunologists recognized the importance of lymphatic vessels as channels for leukocyte trafficking from peripheral sites to their draining LNs (4-6), and as conduits for soluble antigens that can be taken up directly by LNresident $\mathrm{B}$ cells and immature DCs (7-10), which help regulate the kinetics of antigen presentation.

More connections between these two different perspectives have emerged in recent years. Lymphatic endothelial cells (LECs) themselves have been shown to play active roles in controlling their transport functions and in directly communicating with immune cells to modulate their immediate and downstream functions. Indeed, a growing body of evidence is demonstrating how LECs help shape both innate and adaptive immune responses through (a) expression of multiple cytokines, adhesion molecules, and inhibitory receptors; (b) scavenging and processing antigens for direct presentation to $\mathrm{T}$ cells or modulating the activity of professional APCs; and (c) actively regulating fluid and solute transport functions in response to inflammatory signals. These new ideas, in turn, reveal a paradigm whereby the transport and immune functions of lymphatic vessels, which were previously considered separately, are in fact intimately coupled.

In this Review, we highlight these connections to reveal new roles of LECs, along with their transport functions, in modulating adaptive immune responses. While we particularly focus on LEC interactions with DCs and T cells, we also highlight features that support immune regulation, including the structure and function of lymphatic vessels and the compartmentalization of the LN stroma, which help control the manner in which LECs can interface with immune cells. Ongoing research in this area is

Conflict of interest: The authors have declared that no conflict of interest exists. Citation for this article: J Clin Invest. 2014;124(3):943-952. doi:10.1172/JCI73316. essential to understanding how inflammatory lymphangiogenesis affects both cancer progression as well as chronic inflammation that leads to autoimmunity.

\section{Transport and trafficking functions of the lymphatic system}

The lymphatic vessels and secondary lymphoid organs (SLOs) are arranged in a manner that optimizes interactions among antigens, APCs, and innate and adaptive effector cells. SLOs include the spleen, LNs, and Peyer's patches, but this Review focuses on LNs, since LEC/T cell interactions are best described in this compartment.

Lymph flow transports soluble antigens. The LNs serve as hubs of antigen presentation, where lymphocytes are primed or tolerized against antigens presented by APCs. Lymph fluid drained from the periphery via afferent lymphatic vessels bathes LNs with soluble foreign antigens as well as tissue-specific self-antigens and any other molecules present in the local periphery, such as cytokines from inflamed tissues or tumors (10). Because lymph originates as interstitial fluid surrounding the cells of peripheral tissues, it is enriched in peptides that are processed extracellularly, including those resulting from local catabolism, ECM degradation, apoptosis, and tissue remodeling $(9,11)$. While tissue-resident DCs take up and process antigens for presentation on MHC molecules, often resulting in DC maturation and migration to LNs (12), free antigens can rapidly drain to the $\mathrm{LN}$ via the subcapsular sinus, where large antigens and opsonized material may be directly taken up by subcapsular macrophages (Figure 1). Smaller antigens are channeled deeper into the B and T cell zones via intricate conduit systems. In the paracortex, conduits are formed by fibroblastic reticular cells (FRCs) wrapped around bundled collagen fibers $(13,14)$, while in the B cell zone, follicular DCs help form channels for perfusion.

The importance of the B cell conduit system has been demonstrated using two-photon microscopy. For example, Roozendaal and colleagues using two-photon microscopy. They observed that after intradermal injection, lymph-borne antigen rapidly entered the draining LN and either was taken up by subcapsular macrophages (large antigens) or bathed the B cell zone via conduits (small antigens), where antigen-specific B cells efficiently internalized the antigen (14). In the paracortex, immature LN-resident DCs can also take up and present lymph-borne antigen (first wave) prior to the arrival 


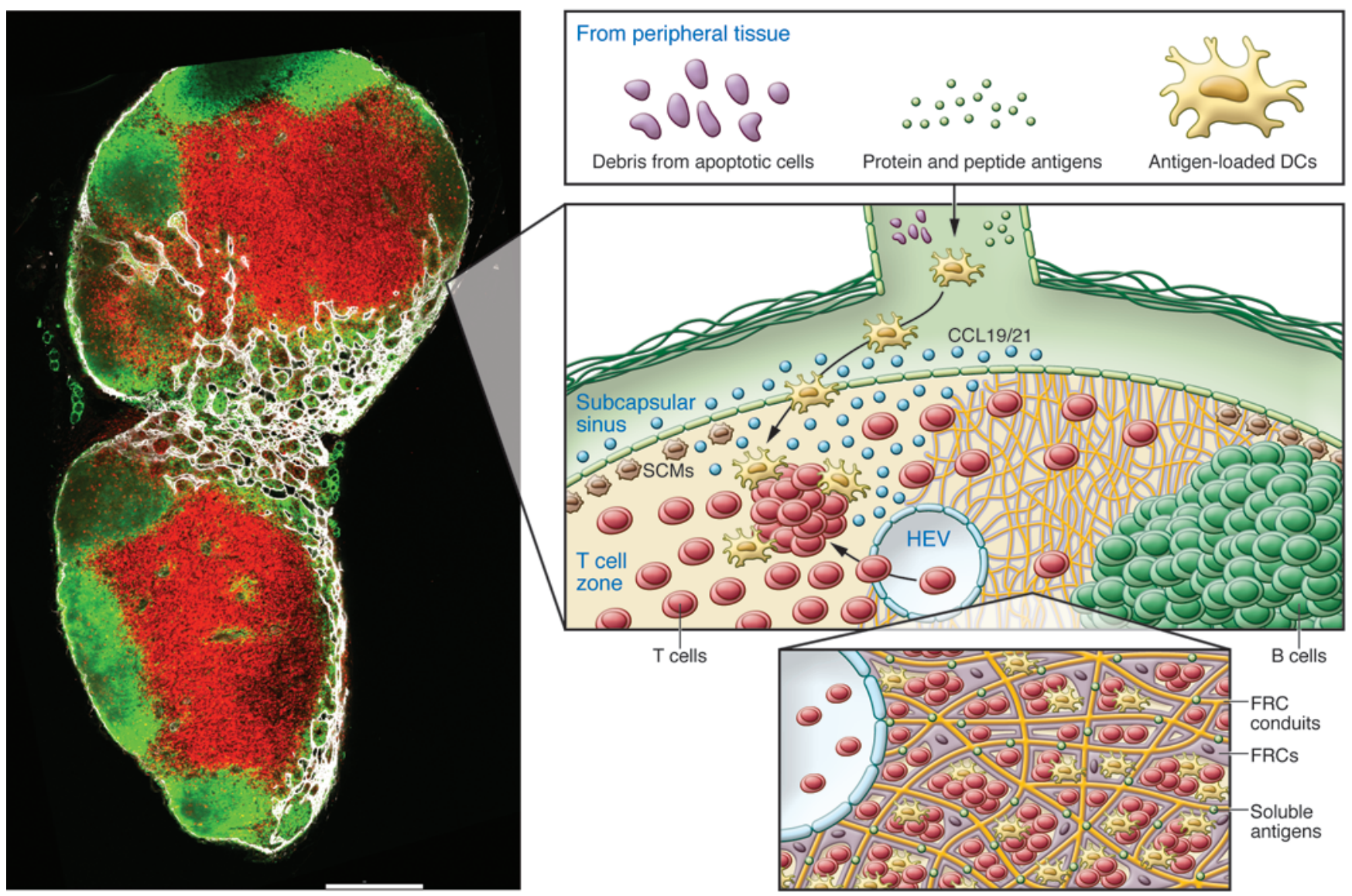

Figure 1

Lymphatic vessels continuously provide local information about the tissues they drain to various cells in the LNs. Lymph-borne antigens may be foreign or self-antigens derived from physiologic cellular metabolism, tissue destruction, and apoptotic cells. Left: immunostained section of a mouse LN shows B cell follicles (B220, green), T cells (CD3e, red), and lymphatic vessels (LYVE-1, white). Right: schematic of the subcapsular sinus, where soluble antigens can access the T cell zone via small conduits enwrapped by FRCs or be taken up by subcapsular macrophages (SCMs). DCs also enter via afferent lymphatic vessels and are attracted by the chemokines CCL19 and CCL21, which bind their receptor CCR7 and which are produced by FRCs and lymphatic endothelium. Naive and regulatory T cells, which also express CCR7, enter mostly through HEVs and less frequently through afferent lymphatics. In the B cell zone, conduits lined by follicular dendritic cells (not shown) enable B cells to rapidly access small antigens that enter from the subcapsular sinus.

of antigen-loaded tissue-resident DCs, which further activates $\mathrm{T}$ cells in a second wave. These differential presentation kinetics have been suggested to fine-tune immune responses, as it is likely that the first wave primes the draining LN for the arrival of the second wave, driving adaptive immune responses (7).

This notion that antigen presentation kinetics help prime as well as control immune responses has profound implications for the importance of lymphatic flow in adaptive immunity. A recent study demonstrated that the absence of soluble antigen transport severely impacts the education of B and T cells in LNs (15). Using K14-VEGFR-3-Ig transgenic mice, which lack dermal lymphatic capillaries but possess intact LNs and otherwise normal lymphatic vasculature, it was shown that intradermal vaccination of these mice led to a drastically reduced antibody response, as expected. However, $\mathrm{T}$ cell activation, although delayed, remained robust even though DC trafficking from the injection site to the draining LN was nearly absent. Whereas $\mathrm{T}$ cell activation took place primarily in the draining LNs in WT mice, this process was found to occur in the spleens of the K14-VEGFR-3-Ig mice. Interestingly, the lack of lymphatic drainage from skin led to autoimmunity in aged mice, and young mice could not be tolerized to exogenous antigen using a classic skin tolerance test (15). Therefore, blocked lymphatic flow prevents soluble antigen transport to the LNs, leading to repercussions in the generation of inflammatory responses against foreign antigens and in the maintenance of peripheral tolerance (16).

Lymph flow is strongly controlled by local tissue inflammation, and various inflammatory cytokines as well as enhanced interstitial flow, which occurs rapidly after tissue injury or infection due to microvascular hyperpermeability, increase both lymph formation and subsequent pumping efficiency of collecting vessels $(17,18)$. In turn, such locally controlled lymph flow regulates immunity both by (a) providing a first wave of soluble antigens after infection or challenge to prime and regulate effector immune responses and (b) providing a constant flow of abundant tissue self-antigens that bathe the LN even under non-infectious conditions to delete autoreactive $\mathrm{T}$ cells.

Lymphatic recruitment of DCs and other migratory cells. We will briefly discuss how LECs facilitate the transport of leukocytes from the periphery, since this is the topic of several excellent recent 
Table 1

LEC expression of cytokines and immunomodulatory enzymes

\begin{tabular}{|c|c|c|c|c|}
\hline Molecule & Immunologic function & Model system & Notes & References \\
\hline CCL1 & $\begin{array}{l}\text { Recruitment of monocytes, NK cells, } \\
\text { T cells, DCs and B cells via CCR8 }\end{array}$ & $\begin{array}{l}\text { Primary human LECs, } \\
\text { human melanoma tissues }\end{array}$ & $\begin{array}{l}\text { Increased by treatment with } \\
\text { LPS, IL-1 } \beta \text {, or TNF- } \alpha\end{array}$ & 55 \\
\hline CCL2 (MCP-1) & $\begin{array}{l}\text { Recruitment of monocytes, DCs, } \\
\text { basophils, and memory T cells via } \\
\text { CCR1, CCR2, and CCR4 }\end{array}$ & $\begin{array}{l}\text { Primary human LECs, } \\
\text { murine LECs in vivo }\end{array}$ & $\begin{array}{l}\text { Increased upon } \\
\text { contact hypersensitivity }\end{array}$ & $\begin{array}{l}23,28 \\
31,32\end{array}$ \\
\hline CCL5 (RANTES) & $\begin{array}{l}\text { Recruitment of T cells and leukocytes } \\
\text { via CCR1, CCR3, CCR4, and CCR5 }\end{array}$ & $\begin{array}{l}\text { Primary human neonatal } \\
\text { dermal LECs }\end{array}$ & $\begin{array}{l}\text { Increased following } \\
\text { TLR3 engagement }\end{array}$ & $28,31,91$ \\
\hline CCL7 (MCP-3) & $\begin{array}{l}\text { Recruitment of monocytes and } \\
\text { regulation of macrophages }\end{array}$ & Murine ear lymphatics & $\begin{array}{l}\text { Increased upon } \\
\text { contact hypersensitivity }\end{array}$ & 23 \\
\hline CCL8 (MCP-2) & $\begin{array}{l}\text { Activation of a range of immune } \\
\text { cells via CCR1, CCR2, CCR3, and CCR5 }\end{array}$ & Murine ear lymphatics & $\begin{array}{l}\text { Increased upon } \\
\text { contact hypersensitivity }\end{array}$ & 23 \\
\hline CCL20 (MIP-3 $\alpha$ ) & $\begin{array}{l}\text { Recruitment of DCs, memory } \\
\text { T cells, and B cells via CCR6 }\end{array}$ & $\begin{array}{l}\text { Primary and cultured human } \\
\text { LECs, murine LECs in vivo }\end{array}$ & $\begin{array}{l}\text { Increased following } \\
\text { TLR stimulation }\end{array}$ & $\begin{array}{c}26,28,31 \\
33,91\end{array}$ \\
\hline CCL21 & $\begin{array}{c}\text { Recruitment of DCs, macrophages, } \\
\text { naive T cells, and regulatory } \\
\text { T cells via CCR7 }\end{array}$ & $\begin{array}{l}\text { Demonstrated in various } \\
\text { mouse models and in } \\
\text { human tissues }\end{array}$ & $\begin{array}{l}\text { Considerable baseline expression } \\
\text { on resting LECs }\end{array}$ & $\begin{array}{l}23,26,33 \\
\quad 42,92\end{array}$ \\
\hline CXCL1 & $\begin{array}{l}\text { Recruits neutrophils via } \\
\text { CXCR1 and CXCR2 }\end{array}$ & Murine LECs in vivo & $\begin{array}{l}\text { Increased upon } \\
\text { contact hypersensitivity }\end{array}$ & 23 \\
\hline CXCL3 & $\begin{array}{l}\text { Recruitment of neutrophils } \\
\text { via CXCR2 }\end{array}$ & $\begin{array}{l}\text { Cultured human } \\
\text { dermal LECs }\end{array}$ & $\begin{array}{l}\text { Increased following } \\
\text { TLR2 stimulation }\end{array}$ & 28,31 \\
\hline CXCL5 & $\begin{array}{l}\text { Recruitment of neutrophils } \\
\text { via CXCR2 }\end{array}$ & $\begin{array}{l}\text { Cultured human dermal } \\
\text { LECs, murine LECs in vivo }\end{array}$ & $\begin{array}{l}\text { Increased upon contact } \\
\text { hypersensitivity and TLR engagement }\end{array}$ & $23,28,31$ \\
\hline CXCL6 & $\begin{array}{l}\text { Recruitment of neutrophils } \\
\text { via CXCR1 and CXCR2 }\end{array}$ & Cultured human dermal LECs & $\begin{array}{l}\text { Increased following } \\
\text { TLR2 stimulation }\end{array}$ & 28,31 \\
\hline CXCL8 & $\begin{array}{l}\text { Recruitment of neutrophils } \\
\text { via CXCR1 and CXCR2 }\end{array}$ & Cultured human dermal LECs & $\begin{array}{l}\text { Increased following } \\
\text { TLR stimulation }\end{array}$ & $28,31,91$ \\
\hline CXCL9 & Recruitment of T cells via CXCR3 & $\begin{array}{l}\text { Cultured human dermal LECs, } \\
\text { murine LECs in vivo }\end{array}$ & $\begin{array}{l}\text { Increased following TLR } \\
\text { stimulation and upon } \\
\text { contact hypersensitivity }\end{array}$ & $\begin{array}{l}23,26 \\
31,91\end{array}$ \\
\hline CXCL10 (IP-10) & $\begin{array}{l}\text { Recruitment and adhesion } \\
\text { of T cells via CXCR3 }\end{array}$ & $\begin{array}{l}\text { Primary and cultured human } \\
\text { LECs, murine LECs in vivo }\end{array}$ & $\begin{array}{l}\text { Upregulated by LPS/IFN- } \gamma \text {, } \\
\text { increased upon contact hypersensitivity }\end{array}$ & $\begin{array}{l}23,26 \\
32,91\end{array}$ \\
\hline CXCL11 & $\begin{array}{l}\text { Recruitment and adhesion of } \\
\text { T cells via CXCR3 }\end{array}$ & Cultured human dermal LECs & Increased following TLR3 engagement & 91 \\
\hline IDO & $\begin{array}{l}\text { Tryptophan-depleting enzyme; inhibits } \\
\text { T cell activation and proliferation }\end{array}$ & $\begin{array}{l}\text { Primary human LECs, murine } \\
\text { tumor-draining LNs }\end{array}$ & $\begin{array}{l}\text { Upregulated following } \\
\text { IFN- } \gamma \text { treatment }\end{array}$ & $32,93,94$ \\
\hline IL-1 $\beta$ & Multiple immunostimulatory effects & Cultured human dermal LECs & Increased following TLR stimulation & 91 \\
\hline IL-6 & $\begin{array}{l}\text { Signals via CD126 and CD130 } \\
\text { to mediate acute } \\
\text { inflammatory responses }\end{array}$ & $\begin{array}{l}\text { Primary and cultured } \\
\text { human LECs }\end{array}$ & Increased following TLR stimulation & 29,91 \\
\hline IL-7 & $\begin{array}{l}\text { Engages CD127 on naive and } \\
\text { memory T cells, leading to their } \\
\text { proliferation and activation } \\
\text { in STAT5-dependent manner }\end{array}$ & Murine primary LECs & $\begin{array}{l}\text { Increased in various } \\
\text { in vivo inflammation models }\end{array}$ & $\begin{array}{l}26,63 \\
79,80\end{array}$ \\
\hline IL-8 & $\begin{array}{l}\text { Recruits neutrophils and } \\
\text { promotes angiogenesis }\end{array}$ & $\begin{array}{l}\text { Primary and cultured } \\
\text { human LECs }\end{array}$ & $\begin{array}{l}\text { Upregulated following } \\
\text { LPS treatment }\end{array}$ & 29 \\
\hline Lipocalin-2 (LCN2) & $\begin{array}{l}\text { Sequesters iron, limits bacterial } \\
\text { growth (involved in innate immunity) }\end{array}$ & Murine primary LECs & $\begin{array}{l}\text { Increased with LPS/OVA } \\
\text { priming and adoptive transfer } \\
\text { of OT-I CD } 8+\text { cells }\end{array}$ & 26 \\
\hline iNOS & $\begin{array}{l}\text { NO catalyst, inhibits } \\
\text { T cell proliferation }\end{array}$ & $\begin{array}{l}\text { Murine LECs engineered } \\
\text { to express OVA in vivo }\end{array}$ & $\begin{array}{l}\text { Upregulated following } \\
\text { IFN- } \gamma \text { treatment }\end{array}$ & 63 \\
\hline TGF- $\beta$ & Multiple immunoregulatory effects & $\begin{array}{l}\text { Primary human neonatal foreskin } \\
\text { LECs, primary murine LECs }\end{array}$ & $\begin{array}{c}\text { Considerable baseline expression } \\
\text { on resting LECs }\end{array}$ & 22,26 \\
\hline TRAIL (TNFSF10) & Induces apoptosis in target cells & Primary murine LECs & $\begin{array}{c}\text { Considerable baseline expression } \\
\text { on resting LECs }\end{array}$ & 26 \\
\hline
\end{tabular}


Table 2

LEC receptors sensing inflammatory or danger signals

\begin{tabular}{|c|c|c|c|c|}
\hline Receptor & Immunologic function & Model system & Notes & References \\
\hline CD120 (TNFR1) & $\begin{array}{l}\text { Heterodimer that responds to TNF- } \alpha \text { by } \\
\text { activating the NF-кB pathways downstream }\end{array}$ & Murine primary LECs & $\begin{array}{c}\text { Considerable baseline expression } \\
\text { on resting LECs }\end{array}$ & 26 \\
\hline CD206 & $\begin{array}{l}\text { Macrophage mannose receptor, } \\
\text { mediates binding and uptake of } \\
\text { multivalent mannosylated motifs }\end{array}$ & $\begin{array}{l}\text { Healthy human tissues } \\
\text { and LNs }\end{array}$ & $\begin{array}{c}\text { Considerable baseline expression } \\
\text { on resting LECs }\end{array}$ & 95 \\
\hline IFNAR1 & $\begin{array}{c}\text { Responds to IFN- } \alpha \text { and IFN- } \beta \text { by } \\
\text { dimerizing with IFNAR2 to activate } \\
\text { multiple Jak/STAT pathways }\end{array}$ & Murine primary LECs & $\begin{array}{c}\text { Considerable baseline expression } \\
\text { on resting LECs }\end{array}$ & 26 \\
\hline IFNAR2 & $\begin{array}{c}\text { Responds to IFN- } \alpha \text { and IFN- } \beta \text { by dimerizing } \\
\text { with IFNAR2 to activate } \\
\text { multiple Jak/STAT pathways }\end{array}$ & Murine primary LECs & $\begin{array}{c}\text { Considerable baseline expression } \\
\text { on resting LECs }\end{array}$ & 26 \\
\hline IFNGR1 & $\begin{array}{l}\text { Responds to IFN- } \gamma \text { by dimerizing with } \\
\text { IFNGR2 to activate the STAT1 pathway }\end{array}$ & Murine primary LECs & $\begin{array}{c}\text { Considerable baseline expression } \\
\text { on resting LECs }\end{array}$ & 26 \\
\hline IFNGR2 & $\begin{array}{l}\text { Responds to IFN- } \gamma \text { by dimerizing with } \\
\text { IFNGR1 to activate the STAT1 pathway }\end{array}$ & Murine primary LECs & $\begin{array}{c}\text { Considerable baseline expression } \\
\text { on resting LECs }\end{array}$ & 26 \\
\hline TLR1 & $\begin{array}{l}\text { Recognizes peptidoglycan and lipoproteins } \\
\text { from gram-positive bacteria }\end{array}$ & $\begin{array}{l}\text { Cultured human dermal } \\
\text { and lung LECs }\end{array}$ & $\begin{array}{c}\text { Considerable baseline expression } \\
\text { on resting LECs }\end{array}$ & 91 \\
\hline TLR2 & $\begin{array}{c}\text { Recognizes gram-positive bacteria } \\
\text { and yeast }\end{array}$ & $\begin{array}{l}\text { Cultured human dermal } \\
\text { and lung LECs }\end{array}$ & $\begin{array}{c}\text { Considerable baseline expression } \\
\text { on resting LECs }\end{array}$ & 31,91 \\
\hline TLR3 & $\begin{array}{l}\text { Recognizes double-stranded RNA } \\
\text { from viral infections }\end{array}$ & $\begin{array}{l}\text { Cultured human dermal } \\
\text { and lung LECs }\end{array}$ & $\begin{array}{c}\text { Considerable baseline expression } \\
\text { on resting LECs }\end{array}$ & 91 \\
\hline TLR4 & $\begin{array}{l}\text { Recognizes LPS (found in most } \\
\text { gram-negative bacteria) }\end{array}$ & $\begin{array}{l}\text { Human intestinal tissue, } \\
\text { cultured neonatal dermal } \\
\text { microvascular LECs }\end{array}$ & $\begin{array}{l}\text { Causes upregulation of ICAM-1 } \\
\text { and VCAM-1 in LECs }\end{array}$ & $29,91,96$ \\
\hline TLR5 & Recognizes flagellin in bacterial flagella & $\begin{array}{l}\text { Cultured human dermal } \\
\text { and lung LECs }\end{array}$ & $\begin{array}{c}\text { Considerable baseline expression } \\
\text { on resting LECs }\end{array}$ & 91 \\
\hline TLR6 & $\begin{array}{l}\text { Recognizes bacterial lippproteins } \\
\text { in concert with TLR2 }\end{array}$ & $\begin{array}{l}\text { Cultured human dermal } \\
\text { and lung LECs }\end{array}$ & $\begin{array}{c}\text { Considerable baseline expression } \\
\text { on resting LECs }\end{array}$ & 91 \\
\hline TLR9 & $\begin{array}{l}\text { Recognizes unmethylated } \mathrm{CpG} \text { sequences } \\
\text { in pathogenic DNA; expressed intracellularly }\end{array}$ & $\begin{array}{l}\text { Cultured human dermal } \\
\text { and lung LECs }\end{array}$ & $\begin{array}{c}\text { Considerable baseline expression } \\
\text { on resting LECs }\end{array}$ & 91 \\
\hline
\end{tabular}

reviews (19-21). LECs both attract and facilitate transmigration of immune cells through a number of signaling axes, many of which have been identified in LEC gene expression studies (22-26). In addition to identifying multiple cytokines and receptors expressed by LECs under steady-state conditions (22), these studies also identified genes that are upregulated during localized inflammatory processes such as in models of contact hypersensitivity (23), tumor drainage (25), and inflammation (26). These studies and others indicate that LECs are capable of expressing and actively signaling through a variety of cytokines and adhesion receptor-ligand interactions important in immunity (Tables 1, 2, and 3 , and refs. 17, 27-30).

LECs express a variety of chemokines that attract DCs as well as other cellular mediators of innate immunity, including monocytes, basophils, and neutrophils (Table 1), although most of these cells rarely migrate to the $\mathrm{LNs}(25,28,31-34)$. Among the most wellstudied is CCL21 (35-38), a lymphoid homing chemokine that binds to CCR7 on migratory DCs, some macrophage subtypes, and naive, central memory and regulatory $\mathrm{T}$ cells, among others (39). Mice lacking CCR7 ligands have drastically impaired DC and $\mathrm{T}$ cell homing to LNs and cannot mount adaptive immune responses there, indicating that CCL21/CCR7 signaling is necessary for cell trafficking from the periphery to LNs (39).
Other chemokines secreted by LECs recruit T and B lymphocytes, which enter the LNs in large numbers to be educated by APCs and to mount effective adaptive immune responses. The recruitment of naive T cells into LNs is controlled by LECs and FRCs via CCL21 and CCL19 (another ligand of CCR7), which are present throughout the cortical zone and eventually transcytosed into the lumen of high endothelial venules (HEVs) (40-42). CCL21 also enhances the affinity of lymphocyte function-associated antigen 1 (LFA-1) on circulating naive T cells for ICAM-1 on blood endothelial cells (BECs), thereby promoting migration $(42,43)$.

LECs can also modulate DC and macrophage trafficking through expression of the chemokine-scavenging decoy receptor D6, which is upregulated in the context of inflammation and tumor drainage (44-47). It has been suggested that D6 helps regulate the extracellular concentrations of its ligands CCL2 and CCL5 (48), as mice deficient for D6 develop exacerbated inflammatory responses (49) and exhibit congestion of the lymphatic vessels by macrophages. Thus, by regulating extracellular CCL2, D6 may help to ensure that lymphatic conduits are uncongested to facilitate DC trafficking (47).

Many adhesion molecules are expressed by LECs to facilitate leukocyte transmigration across LECs. ICAM-1 is important for DC and T cell adhesion and synergizes with CCL21 to promote lymphocyte binding and migration (50). DCs can also transmi- 
Table 3

LEC surface receptors that directly interface with leukocytes

\begin{tabular}{|c|c|c|c|c|}
\hline Molecule & Immunologic function & Model system & Notes & References \\
\hline CD54 (ICAM-1) & $\begin{array}{l}\text { Leukocyte adhesion } \\
\text { via CD11b and ICAM-1 }\end{array}$ & Murine primary LECs & $\begin{array}{l}\text { Increased upon } \\
\text { contact hypersensitivity }\end{array}$ & $\begin{array}{l}17,23,27 \\
29,30\end{array}$ \\
\hline CD58 (LFA-3) & $\begin{array}{l}\text { Engages CD2 on T cells } \\
\text { to enhance cell adhesion }\end{array}$ & Primary human LECs & $\begin{array}{l}\text { Baseline expression levels unaffected } \\
\text { by IFN- } \gamma \text {, TNF- } \alpha \text {, and poly(I:C) }\end{array}$ & 32 \\
\hline CD62E (E-selectin) & $\begin{array}{l}\text { Mediates tethering and rolling } \\
\text { of migrating leukocytes } \\
\text { to endothelial surfaces }\end{array}$ & $\begin{array}{l}\text { Primary and cultured human } \\
\text { LECs, murine LECs in vivo }\end{array}$ & $\begin{array}{l}\text { Increased under various } \\
\text { inflammatory conditions, including } \\
\text { elevated transmural flow }\end{array}$ & $17,28,97$ \\
\hline CD102 (ICAM-2) & $\begin{array}{l}\text { Engages DC-SIGN to support tethering } \\
\text { and rolling of migrating DCs }\end{array}$ & $\begin{array}{l}\text { Primary human tonsilar } \\
\text { LECs, murine primary LECs }\end{array}$ & $\begin{array}{l}\text { Increased in various in } \\
\text { vivo inflammation models }\end{array}$ & 26,98 \\
\hline CD106 (VCAM-1) & $\begin{array}{l}\text { Mediates adhesion of various } \\
\text { leukocyte and lymphocyte } \\
\text { subtypes to endothelial cells }\end{array}$ & Primary human and murine LECs & $\begin{array}{l}\text { Increased upon contact } \\
\text { hypersensitivity or } \\
\text { following TLR engagement }\end{array}$ & $\begin{array}{l}23,26,27 \\
29,30,91\end{array}$ \\
\hline CD200 & $\begin{array}{l}\text { Regulator of myeloid cells } \\
\text { and macrophages }\end{array}$ & Murine tumor-draining LECs & $\begin{array}{l}\text { Increased in tumor-draining } \\
\text { LECs relative to resting LECs }\end{array}$ & 25 \\
\hline MHC class I & $\begin{array}{l}\text { Antigen presentation for } \mathrm{CD}^{+} \\
\mathrm{T} \text { cell recognition }\end{array}$ & $\begin{array}{l}\text { Murine tumor-draining LNs, } \\
\text { murine primary LECs }\end{array}$ & $\begin{array}{c}\text { Considerable baseline expression } \\
\text { on resting LECs }\end{array}$ & $59-61$ \\
\hline MHC class II & $\begin{array}{l}\text { Antigen presentation for } \\
\mathrm{CD} 4^{+} \mathrm{T} \text { cell recognition }\end{array}$ & Murine LECs in vivo & $\begin{array}{l}\text { Increased in various in } \\
\text { vivo inflammation models }\end{array}$ & 26,62 \\
\hline PD-L1 & $\begin{array}{c}\text { Engages PD-1 on activated lymphocytes, } \\
\text { limiting T cell effector activity }\end{array}$ & Murine LECs in vivo & $\begin{array}{l}\text { Increased in various in } \\
\text { vivo inflammation models }\end{array}$ & 62 \\
\hline PTAs & $\begin{array}{l}\text { Library of self-antigens that may be } \\
\text { endogenously expressed in Aire-dependent } \\
\text { manner for presentation to } \\
\text { T cells for tolerogenic deletion }\end{array}$ & $\begin{array}{l}\text { Murine LECs in vivo, } \\
\text { murine LECs engineered } \\
\text { to express OVA in vivo }\end{array}$ & $\begin{array}{l}\text { Considerable baseline expression } \\
\text { on resting LECs }\end{array}$ & $\begin{array}{l}60,61 \\
65,66\end{array}$ \\
\hline Sema3A & $\begin{array}{l}\text { Guides DC migration across lymphatic } \\
\text { endothelium by engagement of Plxa1/Nrp1 }\end{array}$ & $\begin{array}{l}\text { Cultured human and } \\
\text { murine LECs }\end{array}$ & $\begin{array}{c}\text { Considerable baseline expression } \\
\text { on resting LECs }\end{array}$ & 51 \\
\hline
\end{tabular}

grate into the lymphatic vessels using the plexin-A1/neuropilin-1 (Plxa1/Nrp1) receptor complex to engage semaphorin-3A (Sema3A) expressed on LECs (51). These are also upregulated upon inflammatory stimuli (refs. 17, 27-30, and Table 2). For example, elevated local interstitial fluid stresses result in increased fluid flow into the lymphatics, triggering augmented lymphatic secretion of CCL21 and upregulation of ICAM-1 and E-selectin (17). CCR7 signaling may in turn enhance the affinity of LFA-1 on DCs for ICAM-1, suggesting that this may be a synergistic mechanism to facilitate DC homing to LNs following antigenic challenge (43). In this way, antigenic challenge can rapidly lead to changes in lymphatic phenotype that result in enhanced recruitment of DCs and their migration to the LNs, comprising the early stages of an effective antigen-specific, adaptive immune response (Figure 2).

Interestingly, in contrast to K14-VEGFR-3-Ig mice that lack dermal lymphatic capillaries and demonstrate impaired DC migration, Chy mice, which lack the majority of dermal lymphatic capillaries, have rare patches of these vessels in their back skin that express higher levels of CCL21. In these mice, DC migration to LNs draining the back skin appeared normal despite severely impaired lymphatic drainage, indicating that lymphatic density governs fluid and antigen drainage rather than DC migration (52). This has implications for understanding the role of local lymphangiogenesis, where lymphatic vessels expand and become hyperplastic, which occurs in chronic inflammation.

Thus, LECs actively regulate leukocyte trafficking by modulating expression of chemokines and adhesion molecules according to the local state of inflammation in the tissue. LECs can integrate multiple signals, including complement activation products and increased flow as well as most danger signals via TLR signaling (Table 2), allowing them to modulate their differential regulation of leukocyte trafficking or delivery of antigens and local tissue cytokines (17).

LECs regulate entry of immune cells into LNs. Upon arrival at the LNs, migratory DCs exit afferent lymphatic vessels into the subcapsular sinus (53). At this junction, LECs lining the subcapsular sinus express not only CCR7 ligands, but also CCL1, which binds CCR8 on DCs $(5,54,55)$. In this way, LECs may act as gatekeeper cells, selecting $\mathrm{CCR}^{+}$cells for entry into the LNs (55). DCs then traverse the intranodal sinuses in order to gain access to the $T$ cell zone, enabling them to influence downstream adaptive immune responses. The $\mathrm{T}$ cell zone is rich with FRCs, which help guide and module DC-T cell interactions (56).

In addition to lining the subcapsular sinus, LECs also infiltrate into the cortical and medullary sinuses (Figure 1) to presumably direct antigen and leukocytes into the $\mathrm{T}$ cell zone. Although $\mathrm{T}$ cells generally enter LNs via HEVs $(19,57)$, afferent lymph-derived T cells may also enter the parenchyma via medullary sinuses (58). LECs direct lymphocyte trafficking to the medullary sinuses and eventually guide egress of T cells from the LN. As such, T cells frequently encounter LECs throughout their migration through the LN.

Collectively, these data establish that LECs not only express trafficking molecules that affect migration of immune cells, but also possess the appropriate machinery to modulate DC and T cell function. 


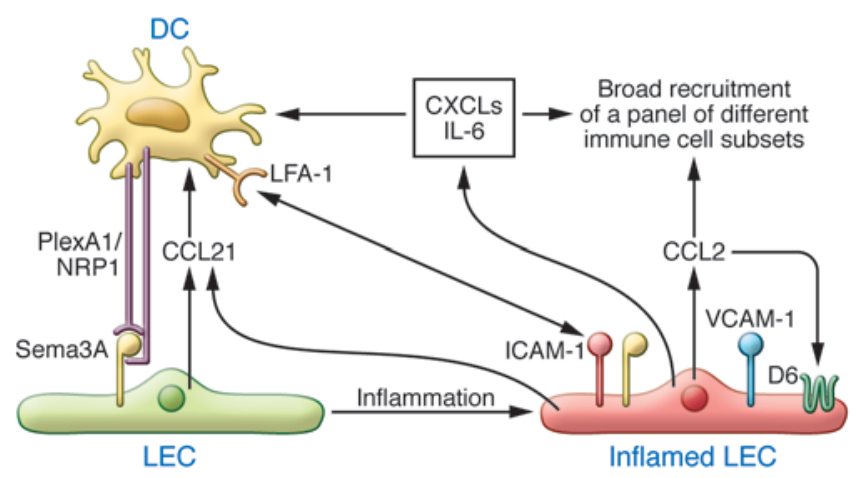

Figure 2

LECs actively recruit leukocytes. Tissue-resident DCs (red) take up antigens in peripheral tissues, home to nearby draining lymphatic vessels via CCL21-driven chemotaxis, and engage ICAM-1, VCAM, and Sema3A for transmigration. Under inflammatory conditions, LECs can increase their expression of adhesion molecules and chemokines that further promote the lymphatic recruitment of DCs and other cell subsets, including macrophages via CCL2. LEC expression of decoy receptors such as D6 helps limit local chemokine concentrations and shape gradients.

\section{Modulation of T cell activation by lymphatics}

$L E C$ s present antigen for $T$ cell regulation. LECs express $M H C$ class I (59-61) and MHC class II $(26,62)$ molecules and can directly induce $\mathrm{T}$ cell tolerance as well as suppress DC-mediated T cell activation. A variety of immunoregulatory factors are expressed by LECs that enable these functions. For example, LECs secrete TGF- $\beta$, indoleamine-2,3-dioxygenase (IDO) and nitric oxide, all of which are immunosuppressive $(22,26,32,63)$. T cell activation is also affected by the relative balance of co-stimulatory and inhibitory receptors on the surface of the activating APC. LECs express high levels of the inhibitory receptor PD-L1 (62) and suboptimal levels of co-stimulatory molecules such as CD80, CD86, and ICOSL (Table 3 and refs. 26, 62).

These expression patterns suggest that LECs may act as APCs. Indeed, several studies have now shown that LECs, as well as other LN stromal cell (LNSC) subsets such as FRCs, can modulate T cell function through direct presentation of endogenous and exogenous antigens (Figure 3). In murine models, LNSCs express various peripheral tissue antigens (PTAs), which they can present to naive $\mathrm{CD} 8^{+} \mathrm{T}$ cells, thus leading to activation and tolerance (61, $64,65)$ due to the absence of co-stimulatory molecules and high levels of PD-L1. Different LNSC subsets, including LECs, FRCs, and BECs, have distinct patterns of PTA expression $(60,66)$, suggesting different roles in modulating responses to these antigens. However, the antigen-presenting capacity of LNSCs seems to be attributable primarily to LECs and FRCs (66). Notably, LECs were the only subset to express the PTA tyrosinase epitope Tyr 369 , a major immunotherapy target for melanoma $(60,66)$. If these observations prove to hold true in humans, LEC-induced tolerance of $\mathrm{Tyr}_{369^{-}}$-specific $\mathrm{CD}^{+} \mathrm{T}$ cells could have a direct impact on the clinical efficacy of anti-melanoma immunotherapies.

The observation that LECs and FRCs can tolerize CD8 ${ }^{+} \mathrm{T}$ cells led to a paradigm shift in models of peripheral tolerance induction, as conventional wisdom attributed suppression of autoreactive $\mathrm{CD}^{+} \mathrm{T}$ cells to activation by quiescent DCs (67). However, the ability of non-hematopoietic cells to induce peripheral $\mathrm{CD}^{+}$ $\mathrm{T}$ cell tolerance is not unique to LECs and FRCs. Liver sinusoidal endothelial cells (LSECs) are considered critical for tolerance to food antigens, as they mount $\mathrm{CD}^{+}$deletional tolerance against exogenous antigens coming directly from the gut $(68,69)$. Tolerance induction by stromal cells is reminiscent of central tolerance induced in the thymus by stromal medullary thymic epithelial cells (mTECs), a process that is dependent on PTA expression driven by the autoimmune regulator Aire (70). Due to the similarities between LNSCs and mTECs, the dependence of Aire in LNSCmediated induction of $\mathrm{CD}^{+} \mathrm{T}$ cell tolerance was investigated. Using a PTA expressed under the Aire promotor, extrathymic Aireexpressing cells (eTACs) were implicated in inducing $\mathrm{CD}^{+} \mathrm{T}$ cell tolerance in SLOs (71). LEC expression of PTAs, including $\mathrm{Tyr}_{369}$, was found to be independent of Aire, whereas PTA expression by double-negative (DN) LNSCs (podoplanin-/CD31-) and CD45 cells was strongly Aire dependent (60). Thus, it remains unknown what drives PTA expression in LECs and FRCs, but both subsets express Deaf1 (60), a transcriptional regulator that induces PTA expression in pancreatic LN (72), suggesting a possible role for this factor in mediating tolerance induced by LECs and FRCs.

There are multiple potential pathways by which peripheral tolerance may be induced. For example, lack of appropriate costimulation or engagement of inhibitory receptors during $\mathrm{CD}^{+}$ $\mathrm{T}$ cell activation results in anergy or deletion. As such, the relative expression of co-stimulatory and inhibitory receptors on APCs influences the outcome of $\mathrm{T}$ cell activation. In the steady state, expression of most co-stimulatory receptors by LECs is low (32, 62), while multiple inhibitory receptors are expressed at high levels (62). In a model of LEC-induced tolerance of $\mathrm{Tyr}_{369}$-specific $\mathrm{CD}^{+} \mathrm{T}$ cells, lack of co-stimulation through CD137 (4-1BB) led to upregulation of PD- 1 and inhibition of CD25 (IL-2R $\alpha$ ) on CD8 ${ }^{+}$ $T$ cells, rendering them resistant to IL-2-mediated pro-survival signaling. Deletion was mediated by PD-L1 expressed on LECs, since blockade of this receptor prevented deletion of $\mathrm{Tyr}_{369}$-specific $\mathrm{CD}^{+} \mathrm{T}$ cells, resulting in autoimmunity (62). This observation was consistent with previous data demonstrating the loss of LNSC-induced $\mathrm{CD}^{+}$tolerance against intestinal PTAs induced by PD-L1 blockade, which led to autoimmune enteritis (73).

In addition to their role in inducing tolerance of autoreactive $\mathrm{CD}^{+} \mathrm{T}$ cells, we recently demonstrated that LECs can scavenge and cross-present foreign antigen to naive $\mathrm{CD}^{+} \mathrm{T}$ cells (59). In this model, B16 F10 melanomas expressed OVA as a foreign antigen, and a second B16 F10 cell line also expressed VEGF-C to enhance tumor and LN lymphangiogenesis. LECs in the tumor-draining LN cross-presented OVA to $\mathrm{CD}^{+} \mathrm{T}$ cells, leading to deletion of OVA-specific CD8 ${ }^{+} \mathrm{T}$ cells. Moreover, VEGF-C-induced lymphangiogenesis further promoted tolerance, and could even protect the tumor against $\mathrm{CD}^{+} \mathrm{T}$ cell immunity (59).

The interactions between LECs and $\mathrm{CD}^{+} \mathrm{T}$ cells are less well described. In the steady state, LECs express low basal levels of MHC class II molecules $(26,32,74)$, and IFN- $\gamma$ induces MHC class II upregulation (32). Although LECs do not express conventional co-stimulatory molecules such as CD80 and CD86, they express LFA-1 (CD58), which can bind CD2 to provide co-stimulation to $\mathrm{T}$ cells. Despite the presence of these molecules, LECs failed to induce $\mathrm{CD}^{+} \mathrm{T}$ cell proliferation or cytokine production in an allogenic co-culture model (32). Thus, while it is now clear that LECs can take up and cross-present exogenous antigens on MHC class I to $\mathrm{CD}^{+} \mathrm{T}$ cells (59), it remains to be seen whether this scavenging activity can lead to antigen presentation on MHC class II and subsequent $\mathrm{CD}^{+} \mathrm{T}$ cell activation. 
A

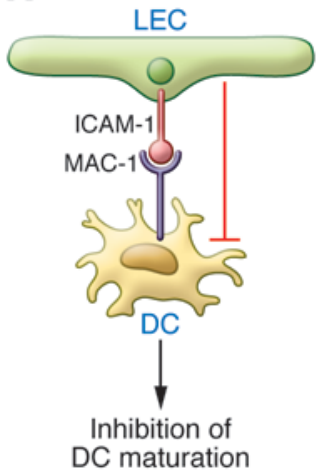

B

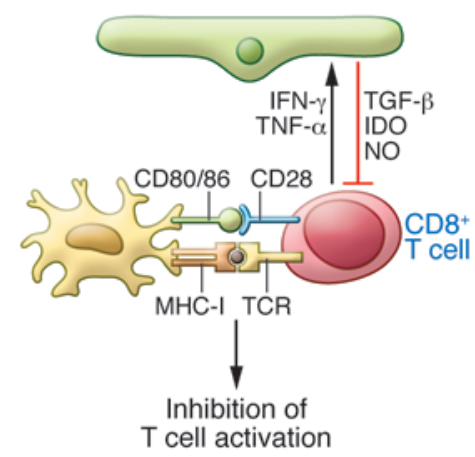

\section{Figure 3}

LECs can suppress immunity and promote tolerance in multiple ways. (A) LECs interact with DCs via binding of ICAM-1 to Mac-1, inhibiting DC maturation and thus dampening their ability to effectively activate T cells. (B) LECs that have been activated by T cell-derived pro-inflammatory cytokines can inhibit $T$ cell proliferation through the production of molecules such as IDO, TGF- $\beta$, and NO, which suppress T cell activation. (C) LECs can directly present endogenous PTAs and cross-present exogenous antigens to naive CD8 ${ }^{+} \mathrm{T}$ cells to induce dysfunctional $\mathrm{T}$ cell activation and tolerance due to expression of the inhibitory receptor PD-L1 and lack of co-stimulatory molecules on the surface of LECs.

Together, these studies suggest that LECs behave like tolerogenic APCs. This assessment is consistent with recent studies showing that LECs deleted self-reactive $\mathrm{T}$ cells in autoimmune disease models and tumor-reactive $\mathrm{CD}^{+}$effectors in a melanoma model $(59,60,62,65)$.

Modulation of $D C-T$ cell interactions by lymphatics. In addition to directly interacting with $\mathrm{T}$ cells, LECs can suppress activation of T cells by DCs $(27,32,63)$. In one study, inflamed LECs suppressed DC maturation, leading to a decreased efficiency in inducing allogenic $\mathrm{T}$ cell proliferation. This interaction was dependent on binding of macrophage- 1 antigen (Mac-1) on DCs to ICAM-1 on LECs and was not observed in the presence of LPS (27). A subsequent study demonstrated that supernatant from IFN $\gamma$-activated LECs also impaired the ability of DCs to induce allogenic $\mathrm{CD}^{+} \mathrm{T}$ cell proliferation, even when DCs were matured with LPS, suggesting that LECs have multiple mechanisms of regulating DC-T cell interactions. Indeed, IFN- $\gamma$-activated LECs produce several molecules that could suppress $T$ cell activation, including IDO, an enzyme that suppresses $\mathrm{T}$ cell proliferation by degrading tryptophan, a substrate required for $T$ cell activation $(32,63)$. However, LECs were later shown to exhibit suppression of $\mathrm{T}$ cell proliferation independent of IDO. In that study, iNOS was found to be responsible for suppression of $\mathrm{T}$ cell proliferation by LECs and FRCs. iNOS catalyzes production of NO, which has suppressive effects on $\mathrm{T}$ cell proliferation and cytokine production. iNOS was upregulated in response to IFN- $\gamma$ and TNF- $\alpha$ produced by activated $\mathrm{T}$ cells that were in direct contact with LECs and FRCs, indicating that bi-directional crosstalk between LNSC and T cells guides regulation of $\mathrm{T}$ cell responses by limiting expansion of activated T cells in LNs (63).

Consistent with a role in induction of peripheral tolerance, a recent report demonstrated that LNSCs cooperate with DCs in order to induce regulatory $\mathrm{T}$ cells in the mesenteric LNs, which are involved in the maintenance of gut homeostasis. In that study, it was suggested that stimuli derived from the gut microbiota enable LNSCs to modulate tolerogenic properties of DCs (75).

C

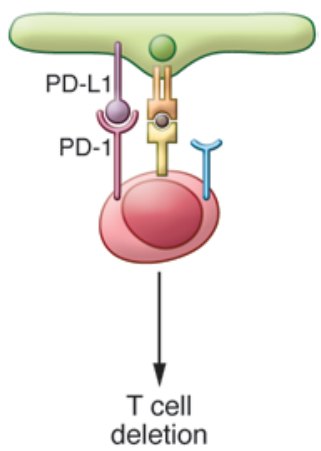

\section{LEC regulation of $\mathrm{T}$ cell homeostasis}

The size, diversity, and distribution of the mature peripheral $\mathrm{T}$ cell pool is tightly regulated through homeostatic pathways affecting migration, proliferation, survival, and apoptosis of activated cells. For example, despite continuous thymic production of mature $\mathrm{T}$ cells, total $\mathrm{T}$ cell numbers remain relatively steady, suggesting that peripheral $\mathrm{T}$ cells are continually lost without compromising the diversity of T cells in circulation (76). As major producers of homeostatic factors, LECs are emerging as important players in regulating the T cell pool, although this notion merits further study.

LECs regulate $T$ cell homeostasis through production of IL-7. IL-7 is a key homeostatic cytokine produced primarily by non-hematopoietic stromal cells. It binds the IL-7R $\alpha$ chain (CD127) in combination with the common $\gamma$-chain (CD132) expressed on developing T, B, and NK lymphocytes, mature $T$ cells, and certain subsets of DCs, macrophages, and innate lymphocytes. In LNs, IL-7 provides survival signals to naive and memory $\mathrm{T}$ cells, which respond by upregulating anti-apoptotic factors and downregulating IL-7R $\alpha$. Disruptions in IL-7 signaling cause imbalances in T cell numbers, such that loss of IL-7 signaling leads to lymphopenia (77).

LNSCs produce high levels of IL-7, which is critical for naive T cell survival (78). Although FRCs were proposed to be the major source of this cytokine due to their presence in $\mathrm{T}$ cell zones of the LN and expression of high levels of $I l 7$ mRNA (78), recent studies demonstrated that LECs produce the most IL-7 in the LN (79-81). Indeed, LECs can support survival of naive T cells in vitro in an IL-7-dependent manner $(79,80)$. Importantly, IL-7 expression by LECs is not restricted to the LN; IL- $7^{+}$LECs have been observed in multiple tissues, including the lung, skin, and gut $(80,81)$, suggesting that LECs may play an important role in the homeostasis of other cells that express functional IL-7 receptors.

Furthermore, T cells may regulate IL-7 production by LECs and FRCs in a negative regulatory loop. Specifically, blockade of lymphocyte entry into LNs induced elevated IL-7 expression in the LN (80), and similarly, LN IL-7 is upregulated during HIV-associated lymphopenia (82). Since T cells may negatively regulate LN lymphangiogenesis (83), it is possible that increased IL-7 is the result of increased numbers of IL- $7^{+}$stromal cells in the absence of T cell regulation. IL-7-expression by embryonic LECs during LN development acts on lymphoid tissue inducer (LTi) cells, promoting their survival and enabling them to drive LN organization (79). In line with this, IL-7 ${ }^{+}$LECs and FRCs were shown to preferentially expand during LN remodeling after destruction by an inflammatory viral infection (79).

$L E C s$ regulate $T$ cell egress from $L N s$. As mentioned above, naive $T$ cells traffic to LNs in a CCR7- and CD62L-dependent manner. These signals also provide cues for $\mathrm{T}$ cell retention within the $\mathrm{LN}$ but are countered by binding of sphingosine-1-phosphate (S1P) to S1P receptor 1 (S1PR1), which triggers migration of lymphocytes into cortical sinuses. However, if a naive $\mathrm{T}$ cell becomes activated by an APC bearing its cognate antigen while in the LN, S1PR1 is 
downregulated, promoting retention of differentiating $\mathrm{T}$ cells in the LN. Following clonal expansion, activated effector and memory T cells downregulate CCR7 and CD62L and upregulate S1PR1, promoting migration to cortical sinuses (84). Within the cortical sinuses, fluid flow also promotes egress of $\mathrm{T}$ cells into efferent lymphatic vessels (85).

While the kinetics of LN egress differs between naive and activated T cells, both are mediated by LECs. Preliminary evidence of this role was provided by studies that demonstrated that, although hematopoietic cells in the periphery produce S1P, radio-resistant cells were responsible for $\mathrm{S} 1 \mathrm{P}$ production in the $\mathrm{LN}$ cortical sinus and efferent lymphatics, implicating a non-hematopoietic cellular source of S1P (86). Further studies utilized mice with deficiencies in S1P production by LYVE- $1^{+}$lymphatics to establish LECs as the source of S1P in these tissues. In the absence of S1P production by LECs, lymphocyte egress from LNs did not occur (87).

During inflammation, lymphocyte egress is transiently shut down but returns to steady-state levels in cases of prolonged inflammation. This restoration in homeostasis is reliant on LECs, as preferential lymphangiogenic expansion of the cortical and medullary sinuses facilitates lymphocyte egress during the late stages of inflammation (88).

Collectively, these studies demonstrate the pivotal role of LECs in controlling the homeostasis of the T cell pool. This is accomplished by coordinated regulation of $\mathrm{T}$ cell survival though IL-7 signaling and by guiding the dissemination of $\mathrm{T}$ cells through production of S1P. Future studies may uncover additional pathways by which LECs and $\mathrm{T}$ cells interact under normal and diseased states.

\section{Clinical significance and future directions for the field}

From a clinical standpoint, an appreciation for interactions been LECs and T cells will be important in several contexts. A major hurdle in the development of cancer immunotherapies is overcoming suppression of anti-tumor T cell responses (89). Evidence reviewed here implicates the lymphatic endothelium in this suppression, which is further exacerbated by lymphangiogenesis in the tumor context (59). Investigating anti-lymphangiogenic therapies may be one way to counter this suppression, thereby improving the efficacy of anti-cancer immunotherapy. HIV presents another example of the potential of therapeutics that target the lymphatic endothelium. In chronic HIV infection, the LN suffers structural damage from inflammation and collagen deposition (90). It is likely that damage to the LN stroma interferes with the regulation of T cell homeostasis by LECs and exacerbates the lymphopenia that is characteristic of progressive HIV disease. In this case, it might be necessary to develop interventions that maintain LN architecture and promote functional interactions between T cells and LNSCs.

In summary, recent studies of lymphatic phenotype and function have demonstrated that LECs are capable of directly shaping the adaptive immune response through influencing immune cell trafficking, promoting $\mathrm{T}$ cell tolerance, and mediating $\mathrm{T}$ cell homeostasis. Furthermore, activated T cells appear to regulate LEC expansion and function in settings of inflammation. It remains to be seen whether LECs can present antigen to $\mathrm{CD}^{+}$ $\mathrm{T}$ cells and what type of response is initiated under those circumstances. In addition, there is a paucity of information on the interactions between LECs and B cells that can modulate immunity. These interactions need to be further delineated to better understand the dynamics of humoral immunity during health and disease. Future development of immunotherapies should consider the pivotal role of lymphatics in shaping immunity and regulating homeostasis of innate and adaptive immune subsets.

\section{Acknowledgments}

We thank Marcela Rincon for the confocal microscopy image of the LN shown in Figure 1. This work was supported by the European Research Council (grant 323053), the Swiss National Science Foundation (grant 31-135756), and the Leenaards Foundation.

Address correspondence to: Melody A. Swartz, EPFL-SV-IBI-LLCB, AI 1106 (Bâtiment AI), Station 15, CH-1015 Lausanne, Switzerland. Phone: 41(0)21.693.9686; Fax: 41(0)21.693.9665; E-mail: melody.swartz@epfl.ch.
1. Aukland K, Reed RK. Interstitial-lymphatic mechanisms in the control of extracellular fluid volume. Physiol Rev. 1993;73(1):1-78.

2. Schmid-Schönbein GW. Microlymphatics and lymph flow. Physiol Rev. 1990;70(4):987-1028.

3. Swartz MA. The physiology of the lymphatic system. Adv Drug Deliv Rev. 2001;50(1-2):3-20.

4. Randolph GJ, Angeli V, Swartz MA. Dendritic cell trafficking to lymph nodes via lymphatic vessels. Nat Rev Immunol. 2005;5(8):1-12.

5. Jakubzick C, Tacke F, Llodra J, van Rooijen N, Randolph GJ. Modulation of dendritic cell trafficking to and from the airways. Immunol. 2006; $176(6): 3578-3584$.

6. Lammermann T, Sixt M. The microanatomy of T-cell responses. Immunol Rev. 2008;221:26-43.

7. Itano AA, et al. Distinct dendritic cell populations sequentially present antigen to CD4 T cells and stimulate different aspects of cell-mediated immunity. Immunity. 2003;19(1):47-57.

8. Wilson NS, et al. Most lymphoid organ dendritic cell types are phenotypically and functionally immature. Blood. 2003;102(6):2187-2194.

9. Clement CC, et al. An expanded self-antigen peptidome is carried by the human lymph as compared to the plasma. PLoS One. 2010;5(3):e9863.

10. Clement CC, Rotzschke O, Santambrogio L. The lymph as a pool of self-antigens. Trends Immunol. 2011;32(1):6-11.
11. Clement CC, et al. Protein expression profiles of human lymph and plasma mapped by 2D-DIGE and $1 D$ SDS-PAGE coupled with nanoLC-ESIMS/MS bottom-up proteomics. J Proteomics. 2013;78:172-187.

12. Banchereau J, Steinman RM. Dendritic cells and the control of immunity. Nature. 1998;392(6673):245-252.

13. Sixt M, et al. The conduit system transports soluble antigens from the afferent lymph to resident dendritic cells in the T cell area of the lymph node. Immunity. 2005;22(1):19-29.

14. Roozendaal R, et al. Conduits mediate transport of low-molecular-weight antigen to lymph node follicles. Immunity. 2009;30(2):264-276.

15. Thomas SN, et al. Impaired humoral immunity and tolerance in K14-VEGFR-3-Ig mice that lack dermal lymphatic drainage. J Immunol. 2012;189(5):2181-2190.

16. Friedlaender $\mathrm{MH}$, Baer H. Immunologic tolerance: Role of the regional lymph node. Science. 1972;176(4032):312-314.

17. Miteva DO, Rutkowski JM, Dixon JB, Kilarski W, Shields JD, Swartz MA. Transmural flow modulates cell and fluid transport functions of lymphatic endothelium. Circ Res. 2010;106(5):920-U181.

18. Zawieja DC. Contractile physiology of lymphatics. Lymphat Res Biol. 2009;7(2):87-96.

19. Girard JP, Moussion C, Foerster R. HEVs, lymphatics and homeostatic immune cell trafficking in lymph nodes. Nat Rev Immunol. 2012;12(11):762-773.

20. Johnson LA, Jackson DG. Cell traffic and the lymphatic endothelium. Ann NY Acad Sci. 2008;1131:119-133.

21. Martin-Fontecha A, Lanzavecchia A, Sallusto F. Dendritic cell migration to peripheral lymph nodes. Handb Exp Pharmacol. 2009;188(188):31-49.

22. Podgrabinska S, et al. Molecular characterization of lymphatic endothelial cells. Proc Natl Acad Sci US A. 2002;99(25):16069-16074.

23. Vigl B, et al. Tissue inflammation modulates gene expression of lymphatic endothelial cells and dendritic cell migration in a stimulus-dependent manner. Blood. 2011;118(1):205-215.

24. Bridenbaugh EA, et al. An immunological fingerprint differentiates muscular lymphatics from arteries and veins. Lymphat Res Biol. 2013;11(3):155-171.

25. Clasper $\mathrm{S}$, et al. A novel gene expression profile in lymphatics associated with tumor growth and nodal metastasis. Cancer Res. 2008;68(18):7293-7303.

26. Malhotra D, et al. Transcriptional profiling of stroma from inflamed and resting lymph nodes defines immunological hallmarks. Nat Immunol. 2012;13(5):499-510.

27. Podgrabinska $S$, et al. Inflamed lymphatic endothelium suppresses dendritic cell maturation and function via Mac-1/ICAM-1-dependent mechanism. J Immunol. 2009;183(3):1767-1779. 
28. Sawa Y, Tsuruga E. The expression of E-selectin and chemokines in the cultured human lymphatic endothelium with lipopolysaccharides. J Anat. 2008;212(5):654-663.

29. Sawa Y, et al. LPS-induced IL-6, IL-8, VCAM-1, and ICAM-1 expression in human lymphatic endothelium. J Histochem Cytochem. 2008;56(2):97-109.

30. Rouzaut A, et al. Dendritic cells adhere to and transmigrate across lymphatic endothelium in response to IFN- $\alpha$. Eur J Immunol. 2010;40(11):3054-3063.

31. Sawa Y, Tsuruga E, Iwasawa K, Ishikawa H, Yoshida S. Leukocyte adhesion molecule and chemokine production through lipoteichoic acid recognition by toll-like receptor 2 in cultured human lymphatic endothelium. Cell Tissue Res. 2008;333(2):237-252.

32. Nörder M, Gutierrez MG, Zicari S, Cervi E, Caruso A, Guzmán CA. Lymph node-derived lymphatic endothelial cells express functional costimulatory molecules and impair dendritic cell-induced allogenic T-cell proliferation. FASEB J. 2012;26(7):2835-2846

33. Kriehuber E, et al. Isolation and characterization of dermal lymphatic and blood endothelial cells reveal stable and functionally specialized cell lineages. J Exp Med. 2001;194(6):797-808.

34. Mori S, Nakano H, Aritomi K, Wang C-R, Gunn $\mathrm{MD}$, Kakiuchi T. Mice lacking expression of the chemokines CCL21-Ser and CCL19 (plt mice) demonstrate delayed but enhanced $\mathrm{T}$ cell immune responses. J Exp Med. 2001;193(2):207-218.

35. Luther SA, Tang HL, Hyman PL, Farr AG, Cyster JG. Coexpression of the chemokines ELC and SLC by $\mathrm{T}$ zone stromal cells and deletion of the ELC gene in the plt/plt mouse. Proc Natl Acad Sci US A. 2000;97(23):12694-12699.

36. Nagira M, et al. Molecular cloning of a novel human CC chemokine secondary lymphoid-tissue chemokine that is a potent chemoattractant for lymphocytes and mapped to chromosome 9p13. J Biol Chem. 1997;272(31):19518-19524.

37. Saeki H, Moore AM, Brown MJ, Hwang ST. Cutting edge: Secondary lymphoid-tissue chemokine (SLC) and CC chemokine receptor 7 (CCR7) participate in the emigration pathway of mature dendritic cells from the skin to regional lymph nodes. J Immunol. 1999;162(5):2472-2475.

38. Willimann $\mathrm{K}$, et al. The chemokine SLC is expressed in $T$ cell areas of lymph nodes and mucosal lymphoid tissues and attracts activated T cells via CCR7. Eur J Immunol. 1998;28(6):2025-2034.

39. Forster R, Davalos-Misslitz AC, Rot A. CCR7 and its ligands: balancing immunity and tolerance. $\mathrm{Nat}$ Rev Immunol. 2008;8(5):362-371.

40. Baekkevold ES, et al. The CCR7 ligand ELC (CCL19) is transcytosed in high endothelial venules and mediates $\mathrm{T}$ cell recruitment. J Exp Med. 2001;193(9):1105-1112.

41. Carlsen HS, Haraldsen G, Brandtzaeg P, Baekkevold ES. Disparate lymphoid chemokine expression in mice and men: no evidence of CCL21 synthesis by human high endothelial venules. Blood. 2005;106(2):444-446.

42. Gunn MD, Tangemann K, Tam C, Cyster JG, Rosen $\mathrm{SD}$, Williams LT. A chemokine expressed in lymphoid high endothelial venules promotes the adhesion and chemotaxis of naive T lymphocytes. Proc Natl Acad Sci U S A. 1998;95(1):258-263.

43. Eich C, et al. The lymphoid chemokine CCL21 triggers LFA- 1 adhesive properties on human dendritic cells. Immunol Cell Biol. 2011;89(3):458-465.

44. Fra AM, et al. Cutting Edge: Scavenging of inflammatory CC chemokines by the promiscuous putatively silent chemokine receptor D6. J Immunol. 2003;170(5):2279-2282.

45. Nibbs RJB, et al. The $\beta$-chemokine receptor D6 Is expressed by lymphatic endothelium and a subset of vascular tumors. Am J Pathol. 2001;158(3):867-877.

46. Vetrano S, et al. The lymphatic system controls intestinal inflammation and inflammation-associated colon cancer through the chemokine decoy receptor D6. Gut. 2010;59(2):197-206.

47. McKimmie CS, et al. An analysis of the function and expression of D6 on lymphatic endothelial cells. Blood. 2013;121(18):3768-3777.

48. Graham GJ. D6 and the atypical chemokine receptor family: Novel regulators of immune and inflammatory processes. Eur J Immunol. 2009;39(2):342-351.

49. de la Torre YM, et al. Increased inflammation in mice deficient for the chemokine decoy receptor D6. Eur J Immunol. 2005;35(5):1342-1346.

50. Stachowiak AN, Wang Y, Huang YC, Irvine DJ. Homeostatic lymphoid chemokines synergize with adhesion ligands to trigger $\mathrm{T}$ and $\mathrm{B}$ lymphocyte chemokinesis. J Immunol. 2006;177(4):2340-2348.

51. Takamatsu H, et al. Semaphorins guide the entry of dendritic cells into the lymphatics by activating myosin II. Nat Immunol. 2010;11(7):594-600.

52. Platt AM, et al. Normal dendritic cell mobilization to lymph nodes under conditions of severe lymphatic hypoplasia. J Immunol. 2013;190(9):4608-4620.

53. von Andrian UH, Mempel TR. Homing and cellular traffic in lymph nodes. Nat Rev Immunol. 2003;3(11):867-878.

54. Qu C, et al. Role of CCR8 and other chemokine pathways in the migration of monocytederived dendritic cells to lymph nodes. J Exp Med. 2004;200(10):1231-1241.

55. Das S, et al. Tumor cell entry into the lymph node is controlled by CCL1 chemokine expressed by lymph node lymphatic sinuses. J Exp Med. 2013;210(8):1509-1528.

56. Mueller SN, Germain RN. Stromal cell contributions to the homeostasis and functionality of the immune system. Nat Rev Immunol. 2009;9(9):618-629.

57. Miyasaka M, Tanaka T. Lymphocyte trafficking across high endothelial venules: dogmas and enigmas. Nat Rev Immunol. 2004;4(5):360-370.

58. Braun A, et al. Afferent lymph-derived $T$ cells and DCs use different chemokine receptor CCR7-dependent routes for entry into the lymph node and intranodal migration. Nat Immunol. 2011;12(9):879-887.

59. Lund AW, et al. VEGF-C promotes immune tolerance in B16 melanomas and cross-presentation of tumor antigen by lymph node lymphatics. Cell Reports. 2012;1(3):191-199.

60. Cohen JN, et al. Lymph node-resident lymphatic endothelial cells mediate peripheral tolerance via Aire-independent direct antigen presentation. J Exp Med. 2010;207(4):681-688.

61. Nichols LA, Chen Y, Colella TA, Bennett CL, Clausen BE, Engelhard VH. Deletional self-tolerance to a melanocyte/melanoma antigen derived from tyrosinase is mediated by a radio-resistant cell in peripheral and mesenteric lymph nodes. J Immunol. 2007;179(2):993-1003.

62. Tewalt EF, et al. Lymphatic endothelial cells induce tolerance via PD-L1 and lack of costimulation leading to high-level PD-1 expression on CD8 T cells. Blood. 2012;120(24):4772-4782.

63. Lukacs-Kornek V, et al. Regulated release of nitric oxide by nonhematopoietic stroma controls expansion of the activated $\mathrm{T}$ cell pool in lymph nodes. Nat Immunol. 2011;12(11):1096-U1105.

64. Magnusson FC, et al. Direct presentation of antigen by lymph node stromal cells protects against CD8 T-cell-mediated intestinal autoimmunity. Gastroenterol. 2008;134(4):1028-1037.

65 . Lee JW, et al. Peripheral antigen display by lymph node stroma promotes $T$ cell tolerance to intestinal self. Nat Immunol. 2007;8(2):181-190.

66 . Fletcher AL, et al. Lymph node fibroblastic reticular cells directly present peripheral tissue antigen under steady-state and inflammatory conditions. J Exp Med. 2010;207(4):689-697.
67. Belz GT, et al. The CD8 $\alpha+$ dendritic cell is responsible for inducing peripheral self-tolerance to tissue-associated antigens. J Exp Med. 2002;196(8):1099-1104.

68. von Oppen N, et al. Systemic antigen cross-presented by liver sinusoidal endothelial cells induces liver-specific CD8 T-cell retention and tolerization. Hepatol. 2009;49(5):1664-1672.

69. Limmer A, et al. Efficient presentation of exogenous antigen by liver endothelial cells to CD8+ T cells results in antigen-specific T-cell tolerance. Nat Med. 2000;6(12):1348-1354.

70. Anderson G, Takahama Y. Thymic epithelial cells: working class heroes for T cell development and repertoire selection. Trends Immunol. 2012;33(6):256-263.

71. Gardner JM, et al. Deletional tolerance mediated by extrathymic Aire-expressing cells. Science. 2008;321(5890):843-847.

72. Yip L, et al. Deaf1 isoforms control the expression of genes encoding peripheral tissue antigens in the pancreatic lymph nodes during type 1 diabetes. Nat Immunol. 2009;10(9):1026-1033.

73. Reynoso ED, et al. Intestinal tolerance is converted to autoimmune enteritis upon PD-1 ligand blockade. J Immunol. 2009;182(4):2102-2112.

74. Amatschek S, et al. Blood and lymphatic endothelial cell-specific differentiation programs are stringently controlled by the tissue environment. Blood. 2007;109(11):4777-4785.

75. Cording $\mathrm{S}$, et al. The intestinal micro-environment imprints stromal cells to promote efficient Treg induction in gut-draining lymph nodes [published online ahead of print August 14, 2013]. Mucosal Immunol. doi:10.1038/mi.2013.54.

76. Almeida ARM, Rocha B, Freitas AA, Tanchot C. Homeostasis of $T$ cell numbers: from thymus production to peripheral compartmentalization and the indexation of regulatory T cells. Semin Immunol. 2005;17(3):239-249.

77. Huang HY, Luther SA. Expression and function of interleukin-7 in secondary and tertiary lymphoid organs. Semin Immunol. 2012;24(3):175-189.

78. Link A, et al. Fibroblastic reticular cells in lymph nodes regulate the homeostasis of naive T cells. Nat Immunol. 2007;8(11):1255-1265.

79. Onder L, et al. IL-7-producing stromal cells are critical for lymph node remodeling. Blood. 2012;120(24):4675-4683.

80. Miller CN, et al. IL-7 production in murine lymphatic endothelial cells and induction in the setting of peripheral lymphopenia. Int Immunol. 2013;25(8):471-483.

81. Hara T, et al. Identification of IL-7-producing cells in primary and secondary lymphoid organs using IL-7-GFP knock-in mice. J Immunol. 2012;189(4):1577-1584

82. Napolitano LA, et al. Increased production of IL-7 accompanies HIV-1-mediated T-cell depletion: implications for T-cell homeostasis. Nat Med. 2001;7(1):73-79.

83. Kataru RP, et al. T lymphocytes negatively regulate lymph node lymphatic vessel formation. Immunity. 2011;34(1):96-107.

84. Schwab SR, Cyster JG. Finding a way out: lymphocyte egress from lymphoid organs. Nat Immunol. 2007;8(12):1295-1301.

85. Grigorova IL, Schwab SR, Phan TG, Pham TH, Okada T, Cyster JG. Cortical sinus probing, S1P1dependent entry and flow-based capture of egressing T cells. Nat Immunol. 2009;10(1):58-65.

86. Pappu R, et al. Promotion of lymphocyte egress into blood and lymph by distinct sources of sphingosine-1-phosphate. Science. 2007;316(5822):295-298.

87. Pham TH, et al. Lymphatic endothelial cell sphingosine kinase activity is required for lymphocyte egress and lymphatic patterning. J Exp Med. 2010;207(1):17-27.

88. Tan KW, et al. Expansion of cortical and medul- 
lary sinuses restrains lymph node hypertrophy during prolonged inflammation. J Immunol. 2012;188(8):4065-4080.

89. Mellman I, Coukos G, Dranoff G. Cancer immunotherapy comes of age. Nature. 2011; 480(7378):480-489.

90. Zeng M, Haase AT, Schacker TW. Lymphoid tissue structure and HIV-1 infection: life or death for T cells. Trends Immunol. 2012;33(6):306-314.

91. Pegu A, Qin S, Fallert Junecko BA, Nisato RE, Pepper MS, Reinhart TA. Human lymphatic endothelial cells express multiple functional TLRs. J Immunol. 2008;180(5):3399-3405.

92. Tomei AA, Siegert S, Britschgi MR, Luther SA,
Swartz MA. Fluid flow regulates stromal cell organization and CCL21 expression in a tissue-engineered lymph node microenvironment. J Immunol. 2009;183(7):4273-4283.

93. Prendergast GC. Immune escape as a fundamental trait of cancer: focus on IDO. Oncogene. 2008;27(28):3889-3900.

94. Shields JD, Kourtis IC, Tomei AA, Roberts JM, Swartz MA. Induction of lymphoidlike stroma and immune escape by tumors that express the chemokine CCL21. Science. 2010;328(5979):749-752.

95. Irjala H, Johansson EL, Grenman R, Alanen K, Salmi M, Jalkanen S. Mannose receptor is a novel ligand for L-selectin and mediates lymphocyte binding to lymphatic endothelium. J Exp Med. 2001;194(8):1033-1042.

96. Sawa Y, Kawamoto T, Yamaoka Y, Notani K, Yoshida S, Inoue N. Expression of toll-like receptors 2 and 4 on human intestinal lymphatic vessels. Microvasc Res. 2004;67(1):90-95.

97. Johnson LA, Clasper S, Holt AP, Lalor PF, Baban D, Jackson DG. An inflammation-induced mechanism for leukocyte transmigration across lymphatic vessel endothelium. J Exp Med. 2006; 203(12):2763-2777.

98. Geijtenbeek TB, et al. DC-SIGN-ICAM-2 interaction mediates dendritic cell trafficking. Nat Immunol. 2000;1(4):353-357. 